\title{
CHARACTERISTICS OF RADIONUCLIDES ON THORIUM-CYCLE EXPERIMENTAL POWER REACTOR SPENT FUEL
}

\author{
R. Andika Putra Dwijayanto, Ihda Husnayani, Zuhair \\ Center for Reactor Technology and Nuclear Safety - BATAN \\ Kawasan Puspiptek Serpong Gd.80, Tangerang Selatan, Banten 15314 \\ e-mail: putra-dwijayanto@batan.go.id \\ (Naskah diterima: 03-06-2019, Naskah direvisi: 20-06-2019, Naskah disetujui: 28-06-2019)
}

\begin{abstract}
CHARACTERISTICS OF RADIONUCLIDES ON THORIUM-CYCLE EXPERIMENTAL POWER REACTOR SPENT FUEL. There are several options of nuclear fuel utilisation in the HTGR-based Experimental Power Reactor (Reaktor Daya Eksperimental/RDE). Although mainly RDE utilises low enriched uranium (LEU)-based fuel, which is the most viable option at the moment, it is possible for RDE to utilise other fuel, for example thorium-based and possibly even plutonium-based fuel. Different fuel yields different spent fuel characteristics, so it is necessary to identify the characteristics to understand and evaluate their handling and interim storage. This paper provides the study on the characteristics of thorium-fuelled RDE spent fuel, assuming typical operational cycle. ORIGEN2.1 code is employed to determine the spent fuel characteristics. The result showed that at the end of the calculation cycle, each thorium-based spent fuel pebble generates around 0,627 Watts of heat, 28 neutrons $/ \mathrm{s}, 8.28 \times 10^{12}$ photons/s and yield 192.53 curies of radioactivity. These higher radioactivity and photon emission possibly necessitate different measures in spent fuel management, if RDE were to use thorium-based fuel. TI-208 activity, which found to be emitting potentially non-negligible strong gamma emission, magnified the requirement of proper spent fuel handling especially radiation shielding in spent fuel cask.
\end{abstract}

Keywords: RDE, spent fuel, thorium, HTGR, TI-208. 


\section{ABSTRAK}

KARAKTERISTIK RADIONUKLIDA PADA BAHAN BAKAR BEKAS REAKTOR DAYA EKSPERIMENTAL SIKLUS THORIUM. Terdapat beberapa opsi pemanfaatan bahan bakar nuklir untuk Reaktor Daya Eksperimental (RDE) berbasis HTGR. Walau RDE utamanya memanfaatan low-enriched uranium (LEU), dimungkinkan juga memanfaatkan bahan bakar lain, misalnya thorium dan plutonium. Bahan bakar berbeda akan menghasilkan karakteristik bahan bakar bekas berbeda pula, sehingga menjadi penting untuk mengidentifikasi karakteristiknya untuk memahami dan mengevaluasi sistem handling dan interim storage yang diperlukan. Makalah ini membahas studi terhadap karakteristik bahan bakar bekas RDE berbahan bakar thorium, mengasumsikan siklus operasional tipikal. Kode komputer ORIGEN2.1 digunakan untuk menentukan karakteristik bahan bakar bekas tersebut. Hasil dari simulasi menunjukkan bahwa, pada akhir siklus perhitungan, tiap

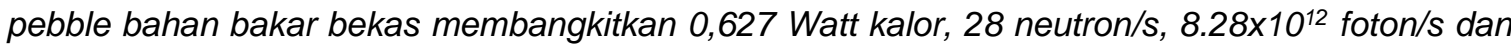
192.53 Curie radioaktivitas. Nilai radioaktivitas dan emisi foton yang lebih tinggi dari bahan bakar LEU mengharuskan penanganan berbeda dalam manajemen bahan bakar bekas, jika RDE menggunakan bahan bakar thorium. Aktivitas TI-208 pun diketahui memancarkan emisi gamma kuat yang mungkin tidak dapat diabaikan, menambah perlunya penanganan bahan bakar bekas yang tepat khususnya terkait perisai radiasi pada kontainer bahan bakar bekas.

Kata kunci: RDE, bahan bakar bekas, thorium, HTGR, TI-208. 


\section{INTRODUCTION}

One of the distinct features between pebble-bed high temperature gas-cooled reactors (HTGRs) and conventional pressurised water reactors (PWRs) is the fuel. Despite both of them use solid oxide fuel, the former shaped the fuel into microencapsulated particles called TRISO (tri-isotropic) dispersed within a graphite ball (pebble). The latter, however, have the fuel pelletised and stacked within zirconium-alloy fuel rod, then arranged into a fuel bundle [1-3].

Compared to the pellet LWR fuel, pebble bed fuel offers several better features. The multi-layered TRISO and the graphite ball act as fission product (FP) retention, preventing the gaseous and volatile FPs to escape into the primary loop. Large thermal margin prevents the fuel from melting, however if it does, albeit unlikely, both TRISO layers and graphite ball will halt the melted fuel from leaking. Micro-sized fuel kernels and graphite ball also provide better heat transfer compared to LWR fuel pellet [4-6].

The Experimental Power Reactor (Reaktor Daya Eksperimental/RDE) proposed by BATAN will adopt the pebble bed HTGR design. Low-enriched uranium (LEU) will make up its fissile fuel, since LEU is readily available. Nevertheless, it is also possible for RDE to use other fuel cycles, possibly uranium-thorium (U-Th), uranium- plutonium (U-Pu), or thorium-plutonium (Th$\mathrm{Pu}$ ). However, different fuel cycle will yield different radionuclides after irradiated in the reactor core, and may result in different behaviour concerning radiation protection of the spent fuel [7-9].

This paper attempts to evaluate the radionuclides characteristics of U-Th pebble for RDE fuel. Among the evaluated characteristics are its radioactivity, decay heat power, and neutron production and photon release rates. Fuel loading scheme assumed in this paper is multi-pass scheme, by which the pebble bed undergoes five cycles of irradiation before being discharged and cooled for five years. The analysis is performed using ORIGEN2.1 code with HTGR-adjusted neutron cross-section library. The code is widely used in radionuclides burnup and decay calculation.

\section{THEORY}

Pebble bed fuel consists of TRISOcoated oxide fuel kernels dispersed within spherical graphite. Each pebble contains thousands of TRISO kernels, for a total of $6 \mathrm{~g}$ heavy metal loading. This study will replace LEU with U-233 and thorium.

One of the unique characteristics of $\mathrm{U}-\mathrm{Th}$ fuel cycle is the existence of U-232, primarily created from two-step reaction involving $(n, 2 n)$ reaction. The $\mathrm{U}-232$ is formed by the mechanism explained as follows [10].

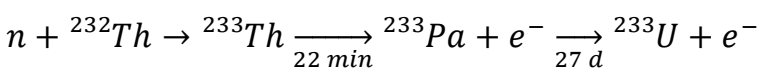

$$
\begin{aligned}
& n+{ }^{233} U \rightarrow 2 n+{ }^{232} U \text { (fast neutron reaction) } \\
& n+{ }^{232} T h \rightarrow 2 n+{ }^{231} T h \underset{1,1 d}{\longrightarrow}{ }^{231} \mathrm{~Pa}+e^{-} \text {(fast) } \\
& n+{ }^{231} \mathrm{~Pa} \rightarrow{ }^{232} \mathrm{~Pa} \underset{1,3 d}{\longrightarrow}{ }^{232} U+e^{-}
\end{aligned}
$$

This isotope decays quickly into TI208, a strong 2.6 MeV gamma emitter $[10,11]$. While it makes the U-Th cycle somehow proliferation-resistant, the gamma emission also complicates its fuel handling.
Thus, its existence is often regarded as nuisance regarding fuel handling system and spent fuel management, and thereby its inventory is critical to be evaluated. 
ORIGEN2.1 is a radionuclide depletion and radioactive decay code used to analysis of spent nuclear fuel compositions as well as radiological characteristics important in designing nuclear facility and safety analyses [12]. This code is widely used since its first inception in 1980s and known for its reliability, and thus used in this study.
ORIGEN works by deterministic method, employing neutron diffusion equation with one-group averaged cross section library. The calculation performed by ORIGEN2.1 by using the differential equation representing build-up and decay of isotopes, shown as follows [13].

$$
\frac{d X_{i}}{d t}=\sum_{j=1}^{N} l_{i j} \lambda_{j} X_{j}+\varphi \sum_{k=1}^{N} f_{i k} \sigma_{k} X_{k}-\left(\lambda_{i}+\varphi \sigma_{i}+r_{i}\right) X_{i}+F_{i}, \quad i=1, \ldots, N
$$

where $X_{i}$ is density of nuclide $i, N$ is number of nuclides, $l_{i j}$ is fraction of radioactive disintegration by other nuclide that leads to formation of species $i, j$ is number of iterations from $j=1$ to $j=N, \varphi$ is positionand-energy averaged neutron flux, $f_{i k}$ is fraction of neutron absorbed by other nuclides that leads to formation of species $i$, $\sigma_{k}$ is spectrum-averaged neutron absorption cross section of nuclide $k, r_{i}$ is continuous removal rate of nuclide $i$ from the system, and $F_{i}$ is continuous feed rate of nuclide $i$.

Reactor-dependent cross-section used in ORIGEN2.1 is adjusted to HTGRspecific one-group cross section, codenamed RDE.LIB. This library has been validated for its employability to calculate inventory in RDE $[14,15]$. The equation, as mentioned above, is then solved using this cross-section, yielding radionuclides results as desired. ORIGEN2. 1 is capable of yielding 130,850 , and 730 nuclides for actinides, FPs, and activation products, respectively [16].

There are two means of depletion scheme provided by ORIGEN, namely IRP (representing constant power) and IRF (constant flux) [17]. Option IRF is especially useful for coupling with other reactor physics codes such as MCNP. However, this study does not involve neutron flux input from other code, thus IRP scheme is employed instead.

Previously, the radionuclide characteristics and inventory of typical RDE fuel has been evaluated $[15,16]$. PBMR spent fuel has also been evaluated and discussed [18], as well as AVR-based spent fuel [19].
These previous studies were also performed using ORIGEN. However, there is yet any evaluation of RDE or HTGR inventory based on the thorium fuel cycle.

\section{METHODOLOGY}

Characterization of radionuclides is determined by simulating burnup and decay of U-Th RDE fuel in ORIGEN2.1. Fuel parameters used in this simulation is provided in Table 1.

Table 1. Thorium RDE fuel parameters

\begin{tabular}{lc}
\hline \multicolumn{1}{c}{ Parameter } & Value \\
\hline Pebble thermal power & $3.7 \mathrm{~kW}$ \\
Fuel type & $(\mathrm{U}, \mathrm{Th}) \mathrm{O}_{2}$ \\
Enrichment level & $8 \%$ \\
Heavy metal loading & $6 \mathrm{~g}$ \\
Mass per pebble & $200 \mathrm{~g}$ \\
Fuel loading scheme & Multi-pass \\
Fuel residence time & 1080 days \\
\hline
\end{tabular}

This study will simulate one pebble instead of the whole core, as an approximation to ideal burnup. Due to complexities of time and space-dependent power change within the core, fuel pebble specific power is set at averaged power of 3.7 $\mathrm{kW} /$ pebble.

There are several possibilities of the U-Th fuel loading within the pebble, as referenced in $[20,21]$. This study employs fuel loading from reference [20], since the reference [21] opted for OTTO cycle. Detailed fuel mass composition is given in Table 2. 
Table 2. Thorium RDE fuel isotopic composition

\begin{tabular}{cc}
\hline Isotope & Mass (g) \\
\hline $\mathrm{U}-232$ & 0.00018 \\
$\mathrm{U}-233$ & 0.41276 \\
$\mathrm{U}-234$ & 0.05669 \\
$\mathrm{U}-235$ & 0.00805 \\
$\mathrm{U}-236$ & 0.00232 \\
Th-232 & 5.52 \\
$\mathrm{O}-16$ & 0.8275 \\
$\mathrm{C}-12$ & 194.674 \\
Si-28 & 1.2896 \\
\hline
\end{tabular}

Apart from accompanying U-232, U-233 generation within nuclear reactor also accompanied by U-234. The latter is created through neutron capture of $\mathrm{Pa}-233$, the intermediate product of Th232 and U-233. It is known that $\mathrm{Pa}-233$ have relatively high neutron capture cross section, combined with its half-life of 27.2 days, lead to generation of $\mathrm{U}-234$, whose existence in reactor is practically useless $[22,23]$. It is capable to absorb neutron, nevertheless, and transmute into U-235 then subsequently U-236, when neutron absorbed by U-235 did not fission.

The extent of uranium isotopes contamination may vary, depending on its production method. Realistically speaking, it is complicated to be able to obtain pure U-233, especially since U-233 online reprocessing system meant to be used in molten salt reactors, whose design is the easiest to obtain pure $\mathrm{U}-233$, is not yet developed in commercial scale [24]. Therefore, as a realistic assumption, this paper refers to reference [25] for the isotopic composition of uranium. It should be noted that the reference [20] employs pure U-233 for the fuel loading instead of contaminated U-233.

It is currently unknown the total residence time of thorium-based fuel in RDE. Since U-233 and thorium perform better in thermal spectrum compared to LEU, thoriumbased fuel is able to stay longer within the core, as demonstrated in other publication [25]. Since the exact time is still inconclusive, however, this study assumes that the fuel will go through the same irradiation pattern with the LEU-based fuel [16]. This may also provide comparable insight between LEU-based and thorium-based fuel.

The fuel pebble is irradiated for five cycles, 216 days each. The waiting time of the pebble before recirculated into the core is assumed at 40 days, judging that there are 125 pebbles being burnt up each day. After the fifth cycle, the pebble is stored and cooled for five years.

\section{RESULT AND DISCUSSIONS}

The result is broken down into four categories, namely radioactivity, neutron emission, photon emission, and thermal power. Special attention is paid to TI-208 isotope.

\section{a. Radioactivity}

There are three categories of radioactivity source calculated by ORIGEN2.1, namely activation products (codename AP), actinides + daughters (ACT), and fission products (FP). Radioactivity characteristics of thoriumbased fuel throughout the irradiation cycle is shown in Figure 1.

At the first 20 days of irradiation, the radioactivity rose sharply above $2000 \mathrm{Ci}$ and continue to increase in a slower rate until the end of first irradiation cycle at day 160 . ACTs build-up and gain more radioactivity share over time. At the end of the fifth cycle, ACTs provide $42 \%$ of radioactivity share. However, this share is not significantly different with the end of the first cycle, of which ACTs provide $39 \%$ of radioactivity share. The sharp decrease in radioactivity during decay at the end of each cycle implies that the FPs and ACTs are predominantly short-lived, especially FPs. 


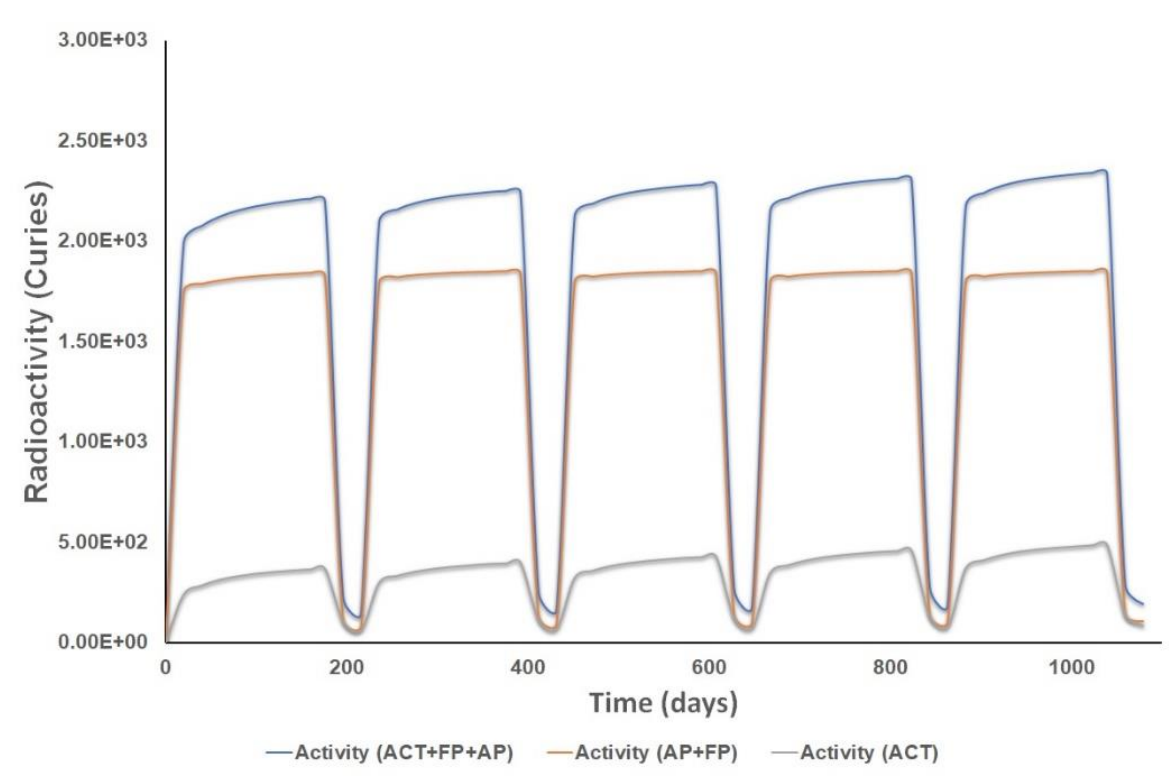

Figure 1. Fuel radioactivity over time

Selected radionuclides in thorium-based spent fuel are shown in the following table. Due to excessive output generated by
ORIGEN2.1, mostly in insignificant amount, only radionuclides with activity above $1 \times 10^{-5}$ $\mathrm{Ci}$ is included in the Table 3

Table 3. Total fuel radioactivity by category at the end of irradiation cycle

\begin{tabular}{|c|c|c|c|c|c|}
\hline \multicolumn{2}{|c|}{ Activation Products } & \multicolumn{4}{|c|}{ Fission Products } \\
\hline Nuclide & Activity (Ci) & Nuclide & Activity (Ci) & Nuclide & Activity (Ci) \\
\hline $\mathrm{H}-3$ & $1.86 \mathrm{E}-04$ & $\mathrm{Kr}-85$ & $1.21 \mathrm{E}-01$ & $\operatorname{Pr}-143$ & $2.59 E+00$ \\
\hline \multirow[t]{4}{*}{ C-14 } & $1.65 \mathrm{E}-05$ & Sr-89 & $8.34 \mathrm{E}+00$ & Ce-144 & $1.22 \mathrm{E}+01$ \\
\hline & & Sr-90 & $1.00 \mathrm{E}+00$ & $\operatorname{Pr}-144$ & $1.22 \mathrm{E}+01$ \\
\hline & & Y-90 & $1.00 \mathrm{E}+00$ & Pr-144m & 1.47E-01 \\
\hline & & $\mathrm{Y}-91$ & $1.09 \mathrm{E}+01$ & $\mathrm{Nd}-147$ & 5.82E-01 \\
\hline \multicolumn{2}{|c|}{ Actinides } & Zr-95 & $1.23 \mathrm{E}+01$ & Pm-147 & $1.67 \mathrm{E}+00$ \\
\hline Nuclide & Activity (Ci) & $\mathrm{Nb}-95$ & $1.64 \mathrm{E}+01$ & Pm-148m & $1.84 \mathrm{E}-01$ \\
\hline TI-208 & 8.22E-04 & $\mathrm{Ru}-103$ & $4.79 \mathrm{E}+00$ & Sm-151 & 4.69E-03 \\
\hline $\mathrm{Pb}-212$ & $2.29 \mathrm{E}-03$ & $\mathrm{Rh}-103 \mathrm{M}$ & $4.31 E+00$ & Eu-154 & 7.68E-02 \\
\hline $\mathrm{Bi}-212$ & $2.29 \mathrm{E}-03$ & $\mathrm{Ru}-106$ & 8.96E-01 & Eu-155 & 4.30E-02 \\
\hline Po-212 & $1.47 \mathrm{E}-03$ & Rh-106 & 8.96E-01 & Eu-156 & $1.30 \mathrm{E}-01$ \\
\hline Po-216 & 2.29E-03 & $\mathrm{Sb}-125$ & 5.27E-02 & & \\
\hline Rn-220 & $2.29 \mathrm{E}-03$ & Te-129m & $1.39 \mathrm{E}-01$ & & \\
\hline Ra-224 & $2.29 \mathrm{E}-03$ & $\mathrm{I}-131$ & 2.93E-01 & & \\
\hline Th-228 & 2.30E-03 & Xe-133 & $1.26 \mathrm{E}-01$ & & \\
\hline Pa-233 & $8.49 E+01$ & Cs-134 & $1.51 \mathrm{E}+00$ & & \\
\hline U-232 & 5.03E-03 & Cs-137 & $1.04 \mathrm{E}+00$ & & \\
\hline U-233 & $2.58 \mathrm{E}-03$ & Ba-137m & $9.84 \mathrm{E}-01$ & & \\
\hline U-234 & 4.42E-04 & $\mathrm{Ba}-140$ & $2.23 \mathrm{E}+00$ & & \\
\hline Pu-238 & $3.12 \mathrm{E}-03$ & La-140 & $2.57 \mathrm{E}+00$ & & \\
\hline Pu-241 & 2.13E-04 & $\mathrm{Ce}-141$ & $7.80 \mathrm{E}+00$ & & \\
\hline \multicolumn{6}{|c|}{ TOTAL $=192.53 \mathrm{Ci}$} \\
\hline
\end{tabular}


Compared to the other two, APs are the least contributing ones, comprising less than half a percent of total radioactivity. Despite possessing relatively long half-life, their low radioactivity makes them less of a concern. Thus, radioactivity from activation products may be considered negligible.

ACTs, as mentioned above, provide a significant contribution to total radioactivity, around 44\%. However, the largest radioactivity from actinides comes from $\mathrm{Pa}$ 233, a short-lived actinide. For this reason, in the longer term, ACTs share of radioactivity diminishes quickly, leaving U-232 and PU238 as the largest contributor of radioactivity. The decay chain of U-232, for instance Th228, Ra-224, Rn-220, and TI-208 also contributes considerably to ACTs radioactivity share.

Typical with thorium fuel cycle, transuranic actinides accumulation is considerably smaller thanks to its longer neutron capture chain. Therefore, contrary to LEU-cycle, transuranic are not as contributing to radioactivity share of ACTs.
FPs are comprised of short and medium-lived isotopes, the largest contributor being $\mathrm{Nb}-95$. One of a major talking point is that Cs-134 provides a larger share of radioactivity compared to LEU-cycle, generating $1.51 \mathrm{Ci}$ at the end of the fifth cycle. In the longer term, caesium isotopes may take over the largest share of radioactivity, since $\mathrm{Nb}-95$ and Zr-95 are comparably shortlived. Thus, spent fuel management of thorium based RDE fuel should consider its activity.

The total radioactivity of thoriumbased spent fuel is $192.53 \mathrm{Ci}$, almost two times larger compared to LEU-cycle spent fuel. This is mainly due to the significant contribution of $\mathrm{Pa}-233$, which accounts for nearly half of radioactivity. Most of the radioactivity will vanish in the first year of cooling, leaving medium and long-lived FPs and ACTs as the remaining source of radioactivity. Afterwards, radioactivity decrease tends to be flat. Pattern of radioactivity decrease over time is shown in Figure 2.

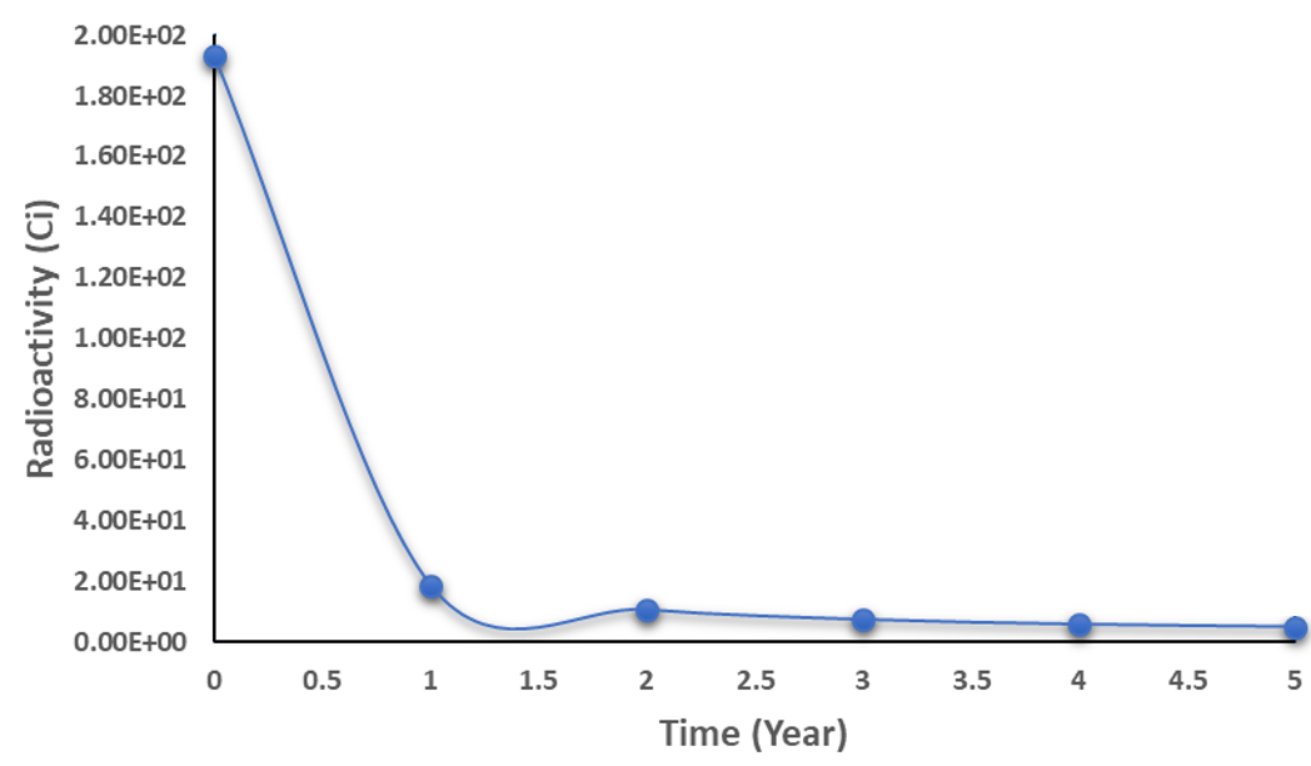

Figure 2. Radioactivity decrease over time

Special attention is paid to $\mathrm{TI}-208$ activity as well as its parent, U-232. The radioactivity of both isotopes for 50 years of decay is shown in the Figure 3. 


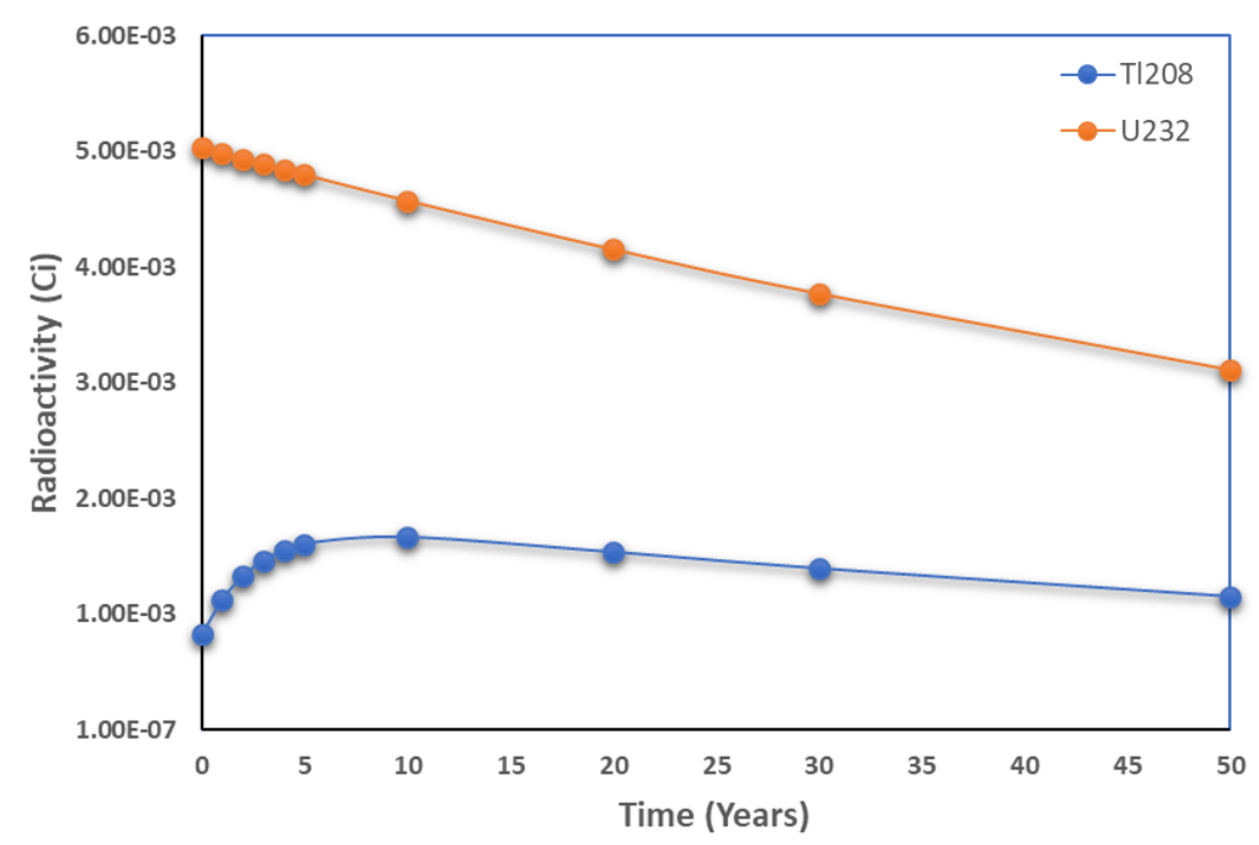

Figure 3. U-232 and TI-208 radioactivity decrease over time

U-232 follows typical decay scheme and continuously decreasing in activity over time. TI-208, however, shows a unique pattern. Its radioactivity is increasing drastically during the first five years, and continue to increase for the next five years albeit considerably flatter. After 10 years, the radioactivity started to decline at a slower rate compared to its increase. At year 50, TI-208 radioactivity lies between $1^{\text {st }}$ and $2^{\text {nd }}$ year radioactivity.

Such peculiar behaviour needs to be taken into account in whole spent fuel management. Despite its relatively low activity (less than $2 \times 10^{-3} \mathrm{Ci}$ per pebble), $\mathrm{Tl}$ 208 releases high-energy gamma radiation nevertheless. Its photon emission will be discussed in the latter part.

\section{b. Neutron emission}

Neutrons from spent fuel are primarily generated through spontaneous fission or (alpha,n) reaction. Several transuranic elements such as Pu-240 and $\mathrm{Cm}-242$ have considerably high spontaneous fission rate, releasing neutrons in the process. However, the thorium fuel cycle generates much less transuranic elements, thereby reducing the total spontaneous fission rate in the spent fuel. In this study, $\mathrm{Pu}$ 238 is the largest contributor, accounting $67 \%$ of total spontaneous neutron fission. Nonetheless, neutrons emitted from spontaneous fission is low, around $7.18 \times 10^{-2}$ neutrons/s.

Meanwhile, (alpha,n) reaction provides more neutron emission than spontaneous fission, generating around 27.28 neutrons/s. The largest emitter being U-232, followed by U-233 and Po-212. In total, each thorium-based RDE spent fuel emits 28 neutrons per second. The value is smaller than LEU-based fuel, thanks to the absence of the large amount of Pu-240 and $\mathrm{Cm}-242$. This may give insight into possible re-criticality accident evaluation on spent fuel management as well as shielding design. The latter, however, still depends significantly on the gamma ray emission discussed in the next part.

Detailed neutron emission from thorium-based RDE spent fuel is provided in Table 4. 
Table 4. Neutron emission from thorium RDE spent fuel at the end of irradiation cycle

\begin{tabular}{cccc}
\hline & (alpha, $\mathbf{n}$ ) & \multicolumn{2}{c}{ Spontaneous } \\
\hline Nuclide & Neutron emission rate (/s) & Nuclide & Neutron emission rate (/s) \\
Bi-212 & $2.013 \mathrm{E}+00$ & Pu-238 & $4.84 \mathrm{E}-01$ \\
Po-212 & $4.269 \mathrm{E}+00$ & $\mathrm{Pu}-240$ & $2.36 \mathrm{E}-03$ \\
Po-213 & $2.234 \mathrm{E}-03$ & $\mathrm{Pu}-242$ & $5.32 \mathrm{E}-04$ \\
Po-216 & $4.101 \mathrm{E}+00$ & $\mathrm{Cm}-242$ & $1.64 \mathrm{E}-01$ \\
Rn-220 & $3.353 \mathrm{E}+00$ & $\mathrm{Cm}-244$ & $6.71 \mathrm{E}-02$ \\
Ra-224 & $2.453 \mathrm{E}+00$ & & \\
Th-228 & $2.090 \mathrm{E}+00$ & & \\
U-232 & $4.273 \mathrm{E}+00$ & & \\
U-233 & $1.486 \mathrm{E}+00$ & & \\
U-234 & $2.457 \mathrm{E}-01$ & \\
Pu-238 & $2.97 \mathrm{E}+00$ & \\
Cm-242 & $3.38 \mathrm{E}-02$ & \\
\hline \multicolumn{4}{c}{ Total: 28 neutrons/s } \\
\hline
\end{tabular}

\section{c. Photon emission}

Photon emission in this context mostly refers to gamma rays emitted by radioactive decay. This is particularly important in evaluating its radiation protection, both in the fuel handling system and spent fuel cask. As previously mentioned, special attention is paid to TI-208.

ORIGEN2.1 generated data for 18 photon energy groups, ranging from 0.01 $\mathrm{MeV}$ to $9.5 \mathrm{MeV}$. At the end of irradiation cycle, total photon emission from ACTs, FPs, and APs is approximately $8.28 \times 10^{12}$. Unlike LEU-based spent fuel, ACTs provides the largest share of photon emission, contributing $57.81 \%$ of the total emission rate.

However, this proves to be only in the first years. At the fifth year, ACTs share of photon emission decreased into $0.43 \%$ of its original value. It shows that highly radioactive ACTs are mostly short-lived. Especially $\mathrm{Pa}$ 233, whose half-life is 27.2 days. Its share slightly increased to $0.67 \%$ at the tenth year as the FPs are decaying at a faster rate than the remaining ACTs and U-232 decay chain isotopes are building up. Since the basis of radiation protection is the largest possible photon emission, total photon emission at the end of the irradiation cycle must be considered nonetheless.

Table 5 show the radioactivity at the end of the irradiation cycle, at the fifth year of decay and tenth year of decay. Figure 4 shows the 18-energy group photon emission from thorium-based RDE spent fuel at the end of the irradiation cycle, after five years of decay and after 10 years of decay.

Table 5. Photon emission rate of thorium-based RDE spent fuel

\begin{tabular}{cccc}
\hline Emission Source & After Irradiation & After $\mathbf{5}$ Years Decay & After 10 Years Decay \\
\hline AP & $7.54 \mathrm{E}+04$ & $2.31 \mathrm{E}+04$ & $2.26 \mathrm{E}+04$ \\
ACT & $4.79 \mathrm{E}+12$ & $5.51 \mathrm{E}+08$ & $5.65 \mathrm{E}+08$ \\
FP & $3.49 \mathrm{E}+12$ & $1.28 \mathrm{E}+11$ & $8.38 \mathrm{E}+10$ \\
Total & $8.28 \mathrm{E}+12$ & $1.29 \mathrm{E}+11$ & $8.44 \mathrm{E}+10$ \\
\hline
\end{tabular}




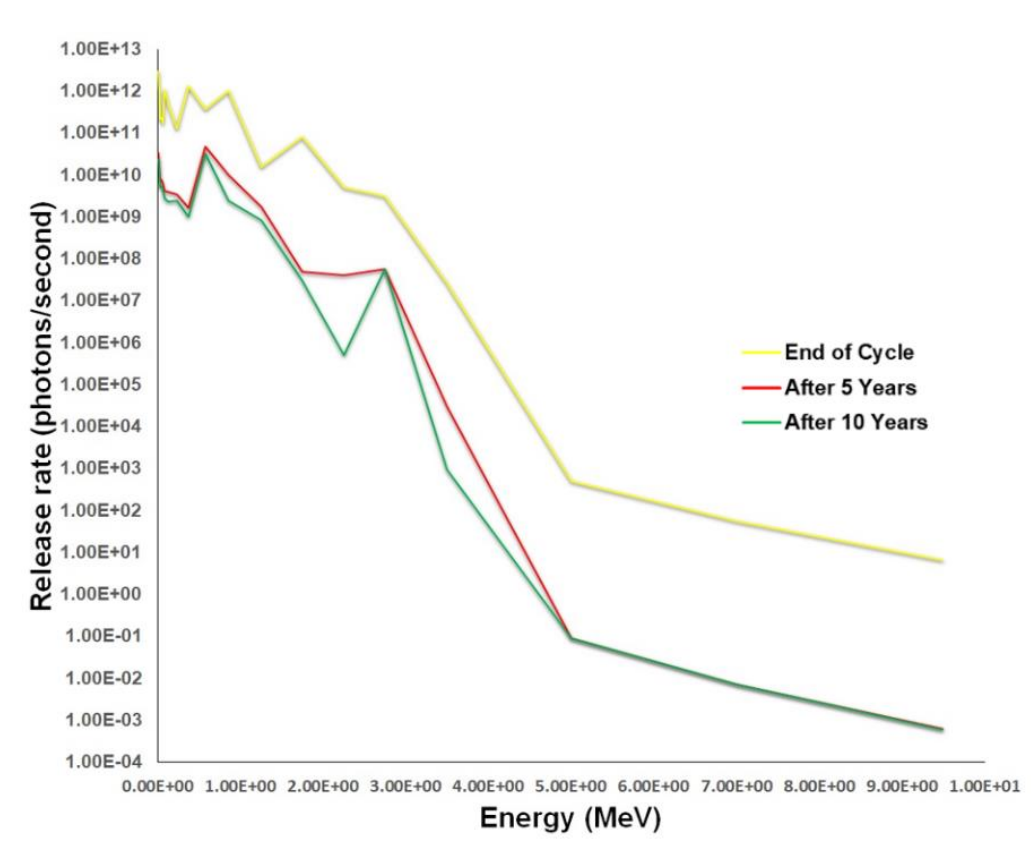

Figure 4. Thorium RDE spent fuel photon emission at the end of irradiation cycle, after five years of cooling, and after 10 years of cooling

Generally, photon emission is decreased as the energy gets higher. However, there is one interesting blip on the energy group $2.75 \mathrm{MeV}$ after 10 years of decay. Instead of decreasing, it has its photon emission higher than the previous group, before dropping once again. It can be understood that the pattern is caused by the existence of TI-208, a $2.6 \mathrm{MeV}$ gamma-ray emitter which activity increases during the first 10 years of decay.

To give better perspective of such pattern, ACTs photon emission rate is shown in the Figure 5.

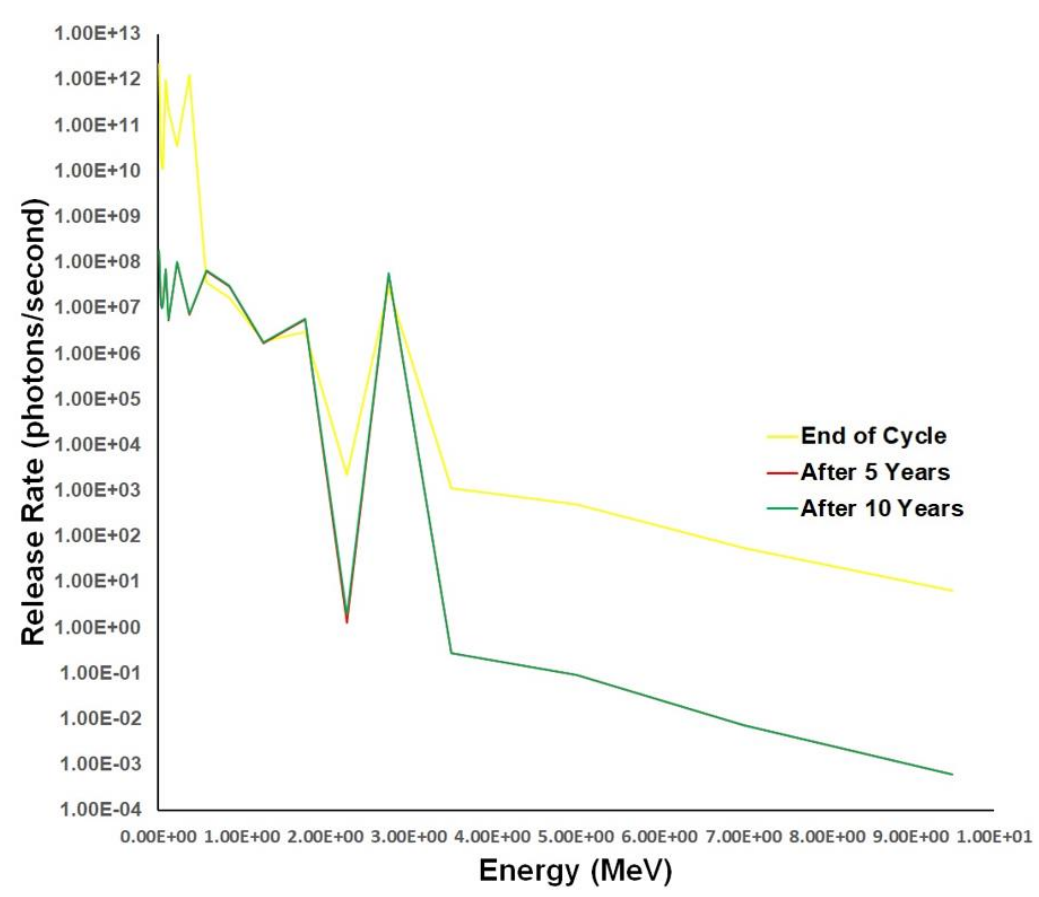

Figure 5. Spent fuel ACTs photon emission at the end of irradiation cycle, after five years of cooling, and after 10 years of cooling 
It is clear that on the $2.75 \mathrm{MeV}$ energy group, the photon emission spiked up from the previous group before dropping down once again. The spiked emission rates are most apparent at the fifth and tenth year of cooling, when Tl-208 activity peaked. Although TI-208 emits considerably low rate of photon compared to lower energy group ACTs, its high energy gamma must be taken into consideration especially in designing its spent fuel cask.

\section{d. Thermal power}

After irradiated, spent fuel still generating heat due to FPs and ACTs decay, known as decay heat. This part is notably essential in term of heat removal mechanism in spent fuel cask. Thermal power source from each category is shown in Table 6.

Table 6. Spent fuel thermal power

\begin{tabular}{cc}
\hline Source Category & Thermal Power (W) \\
\hline AP & $2.97 \mathrm{E}-08$ \\
ACT & $1.94 \mathrm{E}-01$ \\
FP & $4.33 \mathrm{E}-01$ \\
TOTAL & $6.27 \mathrm{E}-01$ \\
\hline
\end{tabular}

In agreement with previous parts, APs also contributes the least in thermal power. Due to low radioactivity and relatively long half-life of the isotopes, APs contribution in total thermal power is considered negligible. Meanwhile, FPs provide the largest share of decay heat, around $69.13 \%$ of total thermal power, while ACTs cover the rest.

Compared to LEU-cycle, thoriumcycle RDE spent fuel generates more heat thanks to $\mathrm{Pa}-233$, which provides $99.6 \%$ of the ACTs decay heat. Since Pa-233 is shortlived, similar to its radioactivity, the decay heat vanishes quickly during the first year after cooling. Nevertheless, there is a unique pattern on ACTs decay heat, as shown in the Table 7.

Despite the instant vanish of the majority of the decay heat during the first year of cooling, the heat release is slowly increasing starting from the second year. Such increase is caused by increasing activity of U-232 decay chain, including Tl-208, Pb212, Bi212, Rn220, Ra224, and Th228. The increase is not particularly significant, nonetheless, and contributes less than $8 \%$ to total thermal power at the year 5 after cooling.

Table 7. ACTs thermal power source over time

\begin{tabular}{cc}
\hline Year & Thermal Power \\
\hline 0 & $1.94 \mathrm{E}-01$ \\
1 & $1.02 \mathrm{E}-03$ \\
2 & $1.11 \mathrm{E}-03$ \\
3 & $1.19 \mathrm{E}-03$ \\
4 & $1.24 \mathrm{E}-03$ \\
5 & $1.27 \mathrm{E}-03$ \\
\hline
\end{tabular}

\section{CONCLUSION}

Thorium-fuelled RDE spent fuel has several distinct characteristics compared to LEU-fuelled RDE spent fuel. One important feature is TI-208 activity, which shows of having potentially non-negligible gamma emission. This is important in radiation protection aspect in designing spent fuel cask, especially since its activity is, uniquely, peaked after 10 years of cooling. The total radioactivity is nearly twice as high as LEU-based spent fuel at the end of irradiation, though it vanished quickly at the first year of cooling and ended up having lower total radioactivity after several years of cooling. Its neutron emission is considerably low, and its thermal power is about $50 \%$ higher compared to LEU-based fuel. Overall, these values give preliminary insight in spent fuel management, which may need a different approach compared to LEUbased fuel.

Since the exact residence time of this fuel is currently unknown, its calculation should be performed in order to provide necessary data to get more accurate representation of thorium-cycle RDE spent fuel. Comparison of spent fuel characteristics for many different uranium isotopic compositions is also necessary. 


\section{ACKNOWLEDGMENTS}

This work is funded by research grant from Ministry of Research, Technology, and Higher Education Republic of Indonesia.

\section{REFERENCES}

[1] Suwoto, H. Adrial, and Zuhair, "Analisis kuat sumber neutron dan perhitungan laju dosis teras awal RDE," Urania, vol. 23, no. 1, pp. 33-44, 2017.

[2] P. M. Udiyani and S. Kuntjoro, "Estimation of routine discharge of radionuclides on power reactor experimental RDE," Urania, vol. 23, no. 1, pp. 45-56, 2017.

[3] K. A. Terrani, D. Wang, L. J. Ott, and R. O. Montgomery. "The effect of fuel thermal conductivity on the behavior of LWR cores during loss-of-coolant accidents," Journal of Nuclear Materials, vol. 448, issue 1-3, pp. 512519, 2014.

[4] S. Parmanto, A. Widiharto, and Y. Sardjono, "Studi desain down scale teras reaktor dan bahan bakar PLTN jenis pebble bed modular reactor HTR 100 MWe," Jurnal Teknologi Reaktor Nuklir, vol. 13, no. 2, pp. 194205, 2011.

[5] S. W. Santoso, A. Widiharto, and Y. Sardjono, "Desain teras dan bahan bakar PLTN jenis pebble bed modular reactor (PBMR) dengan mengunakan program SRAC," Jurnal Teknologi Reaktor Nuklir, vol. 16, no. 2, pp. 109120, 2014.

[6] E. Dewita and S. Alimah, "Analisis Kinerja Bahan Bakar Reaktor Tipe HTGR Sebagai Penghalang Produk Fisi," Jurnal Pengembangan Energi Nuklir, vol. 19, no. 1, pp. 1-9, 2017.

[7] Suwoto, H. Adrial, T. Setiadipura, and Zuhair, "Analisis Perhitungan Distribusi Temperatur Teras dan Reflektor Reaktor Daya Eksperimental." Sigma Epsilon, vol. 20, no. 2, pp. 64-72, 2016.
[8] Zuhair, Suwoto, and H. Adrial, "Studi Performa Teras Inisial HTR Pebble Bed Dengan Bahan Bakar Plutonium Oksida," Sigma Epsilon, vol. 21, no. 1, pp. 1-9, 2017.

[9] Zuhair and Suwoto, "Analisis Efek Kecelakaan Water Ingress Terhadap Reaktivitas Doppler Teras RGTT200K," Jurnal Teknologi Reaktor Nuklir, vol. 17, no. 1, pp. 31-40, 2015.

[10] R. W. Moir, "Recommendations for a restart of molten salt reactor development," Energy Conversion and Management, vol. 49, pp. 1849-1858, 2008.

[11] C. Rubbia, "A Future for Thorium Power?," Thorium Energy for The World, Proceedings of the ThEC13 Conference, Geneva, pp. 9-25, 2013.

[12] U. Mertyurek and I. C. Gauld, "Development of ORIGEN libraries for mixed oxide (MOX) fuel assembly designs," Nuclear Engineering and Design, vol. 297, pp. 220-230, 2016.

[13] I. Husnayani, S. Kuntjoro, and P. M. Udiyani, "Fission products inventory analysis of HTGR fuel by using ORIGEN2.1 computer code," in Prosiding Seminar Nasional Teknologi Energi Nuklir 2016, Batam, pp. 505511.

[14] A. Rohanda, J. S. Pane, and A. Hamzah, "Verifikasi Penggunaan Library ORIGEN2.1 Untuk Perhitungan Inventori Teras Reaktor Tipe HTGR 10MWth," Prosiding Seminar Nasional Teknologi Pengolahan Limbah XIV, Jakarta, pp. 194-198, 2016.

[15] S. Kuntjoro, P. M. Udiyani. "Analisis Inventori Reaktor Daya Eksperimental Jenis Reaktor Gas Temperatur Tinggi," Urania, vol. 22, no. 1, pp. 53-64, 2016.

[16] I. Husnayani, P. M. Udiyani, "Radionuclide characteristics of RDE spent fuels," Jurnal Teknologi Reaktor Nuklir, vol. 20, no. 2, pp. 69-76, 2018.

[17] M. Zheng, W. Tian, H. Wei, D. Zhang, Y. Wu, S. Qiu, and G. Su, 
"Development of a MCNP-ORIGEN burn-up calculation code system and its accuracy assessment," Annals of Nuclear Energy, vol. 63, pp. 491-498, 2014.

[18] C. C. Stoker, F. Reitsma, and Z. Karriem, "Creation of equilibrium core PBMR ORIGEN-S cross section library," HTR2002; Proceedings of the conference on high temperature reactors, Petten, 2002.

[19] Aisyah, Mirawaty, D. L. I. Saputra, and R. Setiawan, "Karakterisasi Radionuklida Pada Bahan Bakar Bekas Dari Experimental Pebble Bed Reactor," Urania, vol. 25, no. 1, pp. 4558, 2019.

[20] Zuhair, Suwoto, and P. I. Yazid, "Investigasi parameter bahan bakar pebble dalam perhitungan teras thorium RGTT200K," Jurnal Sains dan Teknologi Nuklir Indonesia, vol. 14, no. 2, pp. 65-78, 2013.

[21] P. H. Liem, T. M. Sembiring, and H. N. Tran, "Evaluation on fuel cycle and loading scheme on the Indonesian experimental power reactor (RDE) design," Nuclear Engineering and Design, vol. 340, pp. 245-259, 2018.

[22] L. Mathieu, D. Heuer, A. Nuttin, F. Perdu, A. Billebaud, R. Brissot, C. Le Brun, E. Liatard, J. M. Loiseaux, O. Meplan, E. Merle-Lucotte, S. David, C. Garzenne, and D. Lecarpentier, "Thorium Molten Salt Reactor: from high breeding to simplified reprocessing," GLOBAL 2003 Nuclear Science and Technology: Meeting the Global Industrial and $R \& D$ Challenges of the $21^{\text {st }}$ Century, New Orleans, pp. 1863-1872, 2003.

[23] A. Rykhlevskii, J. W. Bae, and. K. D. Huff, "Modeling and simulation of online reprocessing in the thoriumfueled molten salt breeder reactor," Annals of Nuclear Energy, vol. 128, pp. 366-379, 2019.

[24] J. Serp, M. Allibert, O. Benes, S. Delpech, O. Feynberg, V. Ghetta, D. Heuer, D. Holcomb, V. Ignatiev, J. L. Kloosterman, L. Luzzi, E. MerleLucotte, J. Uhlir, R. Yoshioka, D. Zhimin, "The molten salt reactor (MSR) in generation IV: Overview and perspectives," Progress in Nuclear Energy, vol. 77, pp. 308-319, 2014.

[25] D. Heuer, E. Merle-Lucotte, M. Allibert, M. Brovchenko, V. Ghetta, P. Rubiolo, "Towards the thorium fuel cycle with molten salt fast reactors," Annals of Nuclear Energy, vol. 64, pp. 421-429, 2014

[26] X. X. Li, X. Z. Cai, D. Z. Jiang, Y. W. Ma, J. F. Huang, C. Y. Zou, C. G. Yu, J. L. Han, J. G. Chen, "Analysis of thorium and uranium based nuclear fuel options in Fluoride salt-cooled High-temperature reactor," Progress in Nuclear Energy, vol. 78, pp. 285-290, 2015. 
